\title{
CASE REPORT OF EWING SARCOMA OF THE CHEST WALL
}

Zeljko Curcic ${ }^{1}$, Nenad Lujic 1 , Drasko Vasovic 1 , Dejan Vulovic 2 , Jelena Sopta ${ }^{3}$, IInstitute for Orthopedic Surgery "Banjica”, Belgrade, Serbia

2University of Kragujevac, Serbia, Faculty of Medical Sciences, Department of Surgery

3 Institute for Pathology of the Belgrade Faculty of Medicine, Belgrade, Serbia.

\section{PRIKAZ SLUČAJA JUINGOVOG SARKOMA NA GRUDNOM KOŠU}

\author{
Željko Ćurčićl, Nenad Lujićl, Draško Vasović1, Dejan Vulović2 ${ }^{2}$, Jelena Sopta ${ }^{3}$ \\ IInstitut za ortopedsko-hirurške bolesti „,Banjica“, Srbija \\ ${ }^{2}$ Univerzitet u Kragujevcu, Srbija, Fakultet medicinskih nauka, Katedra za hirurgiju \\ 3Institut za patologiju Medicinskog fakulteta, Beograd, Srbija
}

\begin{abstract}
Ewing Sarcoma, a highly malignant and poorly differentiated tumor, is composed of small round cells. Being the second most frequent tumor, it most commonly occurs in children and adolescents, with the gender ratio being 1.5:1 in favor of males. Location-wise, it most often occurs in the area of pelvis, knee, femur and humerus, whereas it is considerably less common in other bones, bones of the head, clavicle or ribs. According to EICESS studies, the forecast, along with adequate treatment, depends on the occurrence of distant metastases. Three-year survival rate of $66 \%$ was reported in patients in whom there were no secondary diseases. The emergence of a large volume tumor, which is primarily localized in the pelvis or the chest, has a poor prognosis.
\end{abstract}

In 2013, a boy born in 2005 presented with a pain in the chest. Upon performed biopsy and verified diagnosis, the case was presented to the Sarcoma Conference, and preoperative chemotherapy was conducted in accordance with the Euro Ewing 2008 protocol. As decided by the Sarcoma Conference, the resection was performed in 2013. The patient is regularly controlled and still without metastatic disease; fully rehabilitated.

The abovementioned case report can lead us to conclude that a serious approach to all symptoms suffered by patients, some of which are often non-specific, is essential. All types of pain should be taken seriously and all necessary diagnostic testing should be immediately performed: to X-ray the affected area, and then, in case of suspected findings, to do a CT of the affected region, as well as skeletal scintigraphy. Tumors of the chest wall are rarely seen in children. Consistent application of the diagnostic system is not less important than the subsequent approach to complete treatment. Surgical therapy must be aggressive to healthy resection surfaces, especially in relapses. Recurrence is not rare, and therefore surgical technique requires special attention.

Ewing's sarcoma serves as an example proving that only a multidisciplinary approach can result in an adequate diagnosis and treatment, as well as in providing patients with higher possibilities of final recovery.

Key words: sarcoma, therapeutics, thorax, neoplasms.

\section{SAZETAK}

Juing sarkom je visokomaligni slabodiferentovani tumor sačinjen od malih okruglih ćelija. Drugi je po učestalosti javljanja, najčešće kod dece i adolescenata. Češće se sreće kod muškog pola, i to u odnosu 1,5:1. Po lokaciji se najčešce javlja u predelu karlice, kolena, femura $i$ nadlaktice, a mnogo ređe na drugim kostima - glave, klavikule, rebara. Prema studijama EICESS, prognoza, uz adekvatno lečenje, zavisi od pojave udaljenih metastaza. Kod bolesnika, kod kojih nije bilo sekundarne bolesti konstatovano je trogodišnje preživljavanje kod 66\%. Pojava tumora velikog volumena koji je primarno lokalizovan u području karlice ili grudnog koša ima lošu prognozu.

Dečak rođen 2005. javio se na pregled zbog bola $u$ predelu grudnog koša 2013. godine. Nakon što je urađena biopsija i postavljena dijagnoza, slučaj je prikazan sarkoma konzilijumu i sprovedena je preoperativna HT, po protokolu Ewing 2008. Sarkoma konzilijum je odlučio da se resekcija obavi 2013. godine. Bolesnik redovno dolazi na kontrole $i$ dalje je bez metastatske bolesti, potpuno rehabilitovan.

Iz navedenog prikaza slučaja možemo zaključiti da je neophodan ozbiljan pristup svim simptomima bolesnika, koji su često nespecifični. Sve bolove treba ozbiljno shvatiti te odmah obaviti svu potrebnu dijagnostiku: rtg zahvaćenog područja, a potom, u slučaju suspektnog nalaza, i CT zahvaćene regije, scintigrafiju skeleta. Tumori zida grudnog koša retko se viđaju kod dece. Veoma je važna dosledna primena sistema dijagnostike, ali nije manje važan ni sledstveni pristup kompletnom lečenju. Hiruršku terapiju treba sprovesti agresivno do zdravih resekcionih površina, posebno kod recidiva. Pojava recidiva nije retka $i$ zato hirurška tehnika zahteva posebnu pažnju.

Juingov sarkom je primer da se samo multidisciplinarnim pristupom može doći do adekvatne dijagnoze, lečenja $i$ pružanja bolesnicima veće mogućnosti za konačno izlečenje.

Ključne reči: sarkom, lečenje, grudni koš, neoplazme. 


\section{INTRODUCTION}

Ewing Sarcoma (ES), a highly malignant and poorly differentiated tumor, is composed of small round cells. Being the second most frequent tumor, it most commonly occurs in children and adolescents, with the gender ratio being 1.5:1 in favor of males. Location-wise, it most often occurs in the area of pelvis, knee, femur and humerus, whereas it is considerably less common in other bones, bones of the head, clavicle or ribs. Upon establishing the differential diagnosis, the application of the staging system is initiated. It is a set of precisely defined diagnostic methods concluded by a biopsy (X-ray, scintigraphy, CT, MR, angiography...). Pathohistological verification is followed by the application of a universally accepted protocol (e.g. EURO EWING protocol), which encompasses preoperative chemotherapy (CHT), appropriately dosed and administered pursuant to the valid protocol, and then, the evaluation of the general and local condition of the patient, based on which consulting body plans surgical treatment. After the surgery, chemotherapy and/or radiotherapy are administered again in accordance with the protocol. Once all planned therapy types and procedures are executed, the patient enters the monitoring phase, primarily involving local control of the disease, as well as systematic controls (monitoring the condition of lungs through radiography and computerized tomography) (Figure 1).

According to EICESS studies, the forecast, along with adequate treatment, depends on the occurrence of distant metastases. Three-year survival rate of $66 \%$ was reported in patients in whom there were no secondary diseases. The emergence of a large volume tumor, which is primarily localized in the pelvis or the chest, has a poor prognosis. [16]

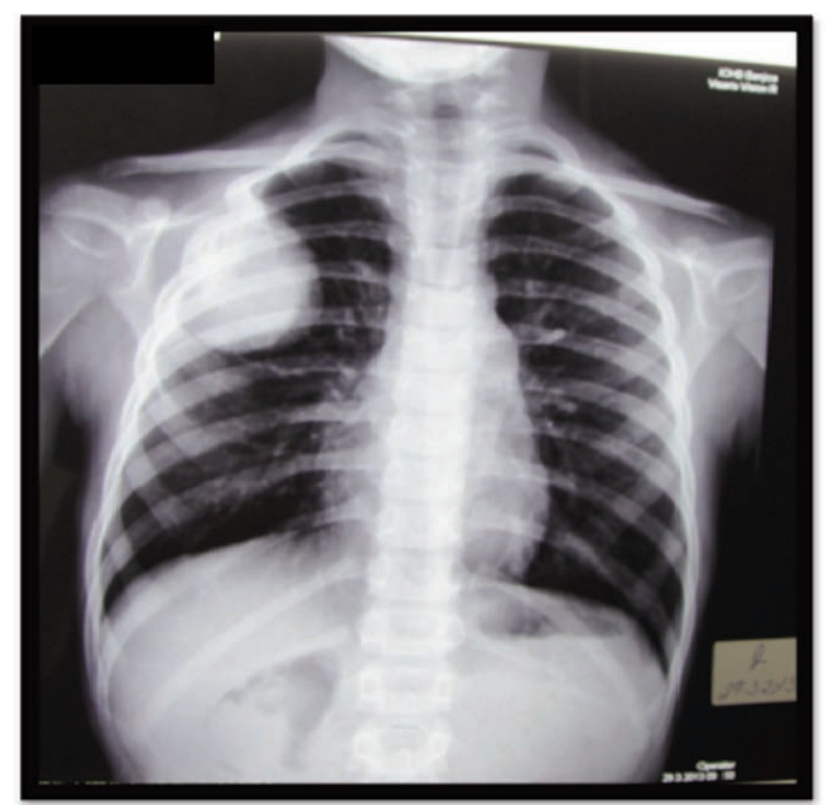

Figure 1. - Initial radiography (X-ray) of the chest before the biopsy.

\section{CASE REPORT}

In 2013, a boy born in 2005 (aged 9 upon admission) presented with a pain in the chest. The period from the occurrence of first symptoms to the admission to hospital (on March 27th, 2013) involved around three months (which would have accounted for the "lost time fund"). Radiography of the chest was performed first, revealing a great shadow in the area between the second and the sixth rib of the right chest. (Figure 2)

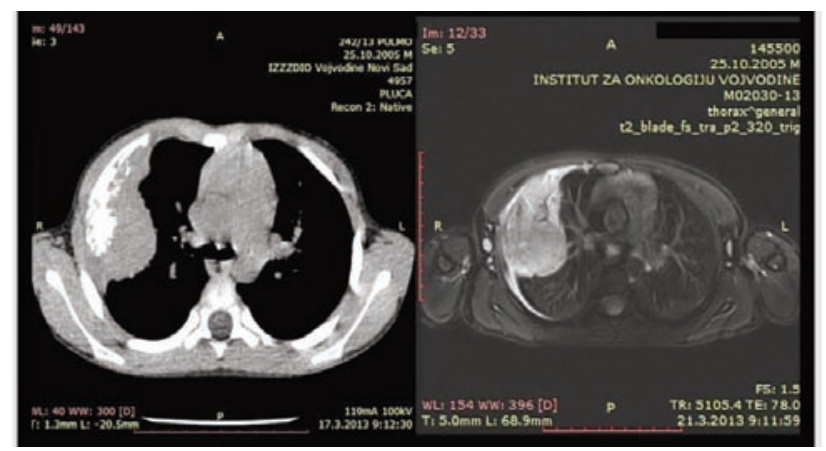

Figure 2. - Initial CT scan and magnetic resonance (MR) shots of the chest before the biopsy.

Then, the patient underwent a CT scan of the chest showing a third rib tumefact of a large volume, which appeared as original bone tumor with the characteristics of malignancy. Afterwards, the biopsy was performed (on April 10 th 2013 ) and the diagnosis was set (Ewing Sarcoma/PNET). The patient was presented to the Sarcoma Conference (SC), and preoperative CHT was conducted in accordance with the Euro Ewing 2008 protocol. Preoperative CHT was administered in four cycles and postoperative in six cycles. (Figure 3 ).

Upon the reevaluation and the first four cycles of chemotherapy, a resection was executed (on September $2^{\text {nd }}$, 2013) following the decision of the Sarcoma Consulting Body. Histopathological diagnostics was performed at the Institute for Pathology of the Belgrade Faculty of Medicine.

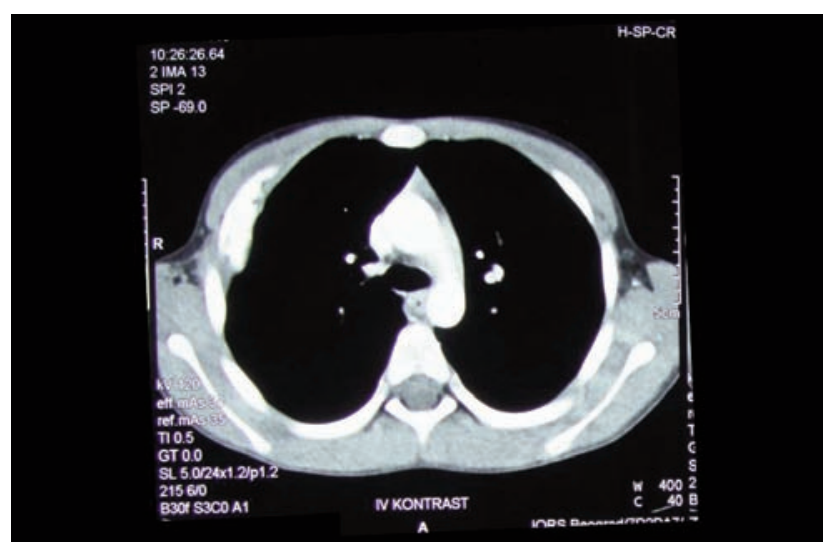

Figure 3. - CT scan of the chest after preoperative chemotherapy (CHT) (preparation for surgical treatment) 
The entire resected rib segment was analyzed, previous diagnosis was reconfirmed, and clean surgical boundaries and massive post-therapeutic necrosis of $99 \%$ were reported. The patient is regularly controlled and still without metastatic disease; fully rehabilitated. [7-9] (Figure 4).

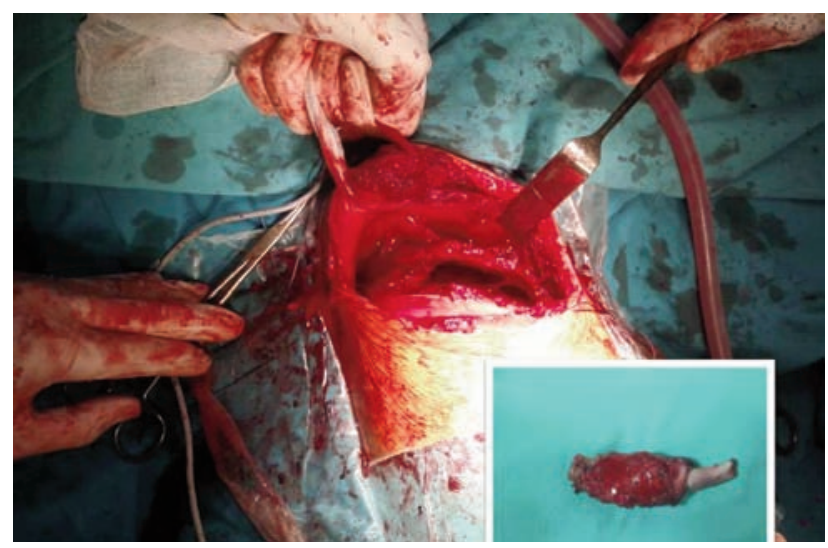

Figure 4. - Operational field when performing the resection surgery and specimen, resected Ewing Sarcoma of the chest.

\section{DISCUSSION}

The above mentioned case report can lead us to conclude that a serious approach to all symptoms suffered by patients, some of which are often non-specific, is essential. And only such an approach can produce these results. All types of pain should be taken seriously and all necessary diagnostic testing should be immediately performed: first, radiography of the affected area, and then, in case of suspected findings, doing a CT of the affected region, as well as skeletal scintigraphy. Tumors of the chest wall are rarely seen in children. Consistent application of the diagnostic system is not less important than the subsequent approach to complete treatment. Surgical therapy must be aggressive to healthy resection surfaces, especially in relapses. Recurrence is not rare, and therefore surgical technique requires special attention. (Figure5).

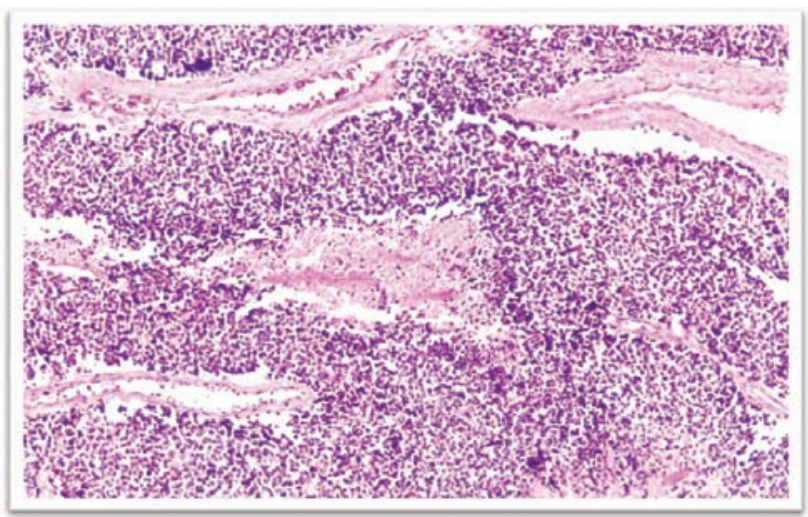

Figure 5. - Photomicrography, histopathological analysis Ewing Sarcoma of the rib, of the thorax. (standard paint)
Nonetheless, one may claim that the role of Sarcoma Consulting Body is of crucial significance, along with applying the staging system. Ewing's sarcoma serves as an example proving that only a multidisciplinary approach can result in an adequate diagnosis and treatment, as well as in providing patients with higher possibilities of final recovery. [10-12]

\section{REFERENCES}

1. Fletcher DM, Unni KK, Martens F. WHO Classification of tumors of soft tissue and bone pathology \& Genetics. In: Kleihues P, Sobin LH, editors. Lyon: IACP Press. 2002; 12-8, 227-32, 309-13.

2. Jaffe HL. Tumors and Tumors Conditions of the bones and joints. In: Jaffe HL, editor. London: Lea \& Febiger 1972; 312-9.

3. Enneking WF, Berrey HB, Scarborough TM, Vander Griend AR. Clinical musculoskeletal pathology. In: Berrey HB, Scarborough TM, editors. Florida: UF Press Gainesville 1997; 21-9.

4. Enneking WF, Spanier SS, Goodman MA. A system for the surgical staging of musculoskeletal sarcoma. Clin Orthop Relat Res 1980; 153: 106-20.

5. Mirra MJ, Picci P, Gold RH. Bone Tumors. In: Mirra MJ, editor. London: Lea \& Febiger; 1989; 941-1020.

6. Enneking WF. Stagging of muscosceletal tumors in musculoskeletal surgery. In: Enneking WF, editor. New York: Churchill-Livingstone 1983; 1468-76.

7. Lopez C., Correa A., Vaporciyan C. A., Austin M., Rice D., Hayes-Jordan A. Outcomes of chest wall resections in pediatric sarcoma patients, Journal of Pediatric Surgery 2017; 52, 109-14.

8. Pfannschmidt J, Geisbusch P, Muley T, Hoffmann H, Dienemann H. Surgical resection of secondary chest wall tumors. Thorac Cardiovasc Surg 2005; 53:234-9.

9. Simal I, García-Casillas MA, Cerdá JA, et al. Threedimensional custom-made titanium ribs for reconstruction of a large chest wall defect. European Journal of Pediatric Surgery Reports 2016; 4: 26-30.

10. Gross JL, Younes RN, Haddad FJ, Deheinzelin D, Pinto CA, Costa ML. Soft-tissue sarcomas of the chest wall: prognostic factors. Chest 2005; 127: 902-8.

11. Franzettil GA, Laud-Duval K, Van der Ent W, et al. Cellto-cell heterogeneity of EWSR1-FLI1 activity determines proliferation/migration choices in Ewing sarcoma cells. 2017; Oncogene 1: 498.

12. Noujaim J, Jones LR, Swansbury J, et al. The spectrum of EWSR1-rearranged neoplasms at a tertiary sarcoma center; assessing 772 tumor specimens and the value of current ancillary molecular diagnostic modalities. British Journal of Cancer 2017; 1: 116. 